ROMAN SOWA ${ }^{1,2}$, SEBASTIAN ARABASZ $Z^{3}$ MAGDALENA PARLINSKA-WOJTAN ${ }^{*}$

${ }^{1}$ Institute of Nuclear Physics Polish Academy of Sciences, Krakow, Poland, ${ }^{2}$ MTU Aero Engines Polska, Jasionka, Poland, ${ }^{3}$ Labsoft SA, Warszawa, Poland

\section{Scientific paper}

ISSN 0351-9465, E-ISSN 2466-2585

UDC: 620.1867 .187 .669 .248

doi:10.5937/ZasMat1602274S

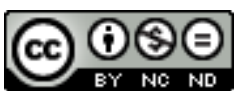

Zastita Materijala 57 (2)

$274-281$ (2016)

\title{
Classification and microstructural stability of high generation single crystal nickel-based superalloys
}

\begin{abstract}
This paper presents a brief review on various types of single crystal Ni-based superalloys designed over the recent years. The design principles to achieve required mechanical properties and microstructural stability over the long time exposure to high temperatures are emphasized. The main attention is given to alloys with a high content of refractory elements. In particular the formation of brittle phases, like topologically close packed (TCP) phases, degrading mechanical properties of the Ni-based superalloys is emphasized.
\end{abstract}

Keywords: Ni-based superalloys, TCP phases, Gamma, Gamma Prime

\section{INTRODUCTION}

The development of advanced heat resistant alloys is one of the methods, besides cooling and coating systems, to improve thermal efficiency of aircraft engines. To achieve high temperature capabilities in terms of hot corrosion resistance and creep-rupture strength various series of nickelbased superalloys are constantly developed. Superalloys are a group of nickel, iron-nickel, and cobalt based materials with excellent strength and surface stability. They have been employed for the hottest areas of aircraft and industrial gas turbine engines. In general, they can be divided into two groups: wrought and cast ones. Wrought alloys exhibit good fracture toughness and high strength up to around $870^{\circ} \mathrm{C}$; they can be forged or rolled into sheets, rods, or turbine discs [1]. On the other hand, cast alloys possess outstanding creep strength at high temperatures up to $85 \%$ of their melting point [2]. Depending on casting process, three main types of cast superalloys can be distinguished: conventionally cast (CC), directionally solidified (DS) and single crystal (SC). Compared to CC and DS, the SC ones exhibit

${ }^{*}$ Corresponding author: Magdalena Parlinska-Wojtan E-mail: bpparlin@cyf-kr.edu.pl

Paper received: 09. 02. 2016.

Paper accepted: 24. 03. 2016.

Paper is available on the website: www.idk.org.rs/journal enhanced high temperature mechanical properties, mainly due to elimination of grain boundaries as potential failure initiation sites. Modern SC superalloys contain high levels of refractory elements, such as Mo, W, Re in order to increase high temperature creep and rupture properties [3, 4]. However, high content of these elements makes the alloys more susceptible to the formation of TCP phases during long-term service [5]. These phases were shown to have detrimental effect on mechanical properties of polycrystalline alloys [6]. Although the developers of high-strength single crystal superalloys try to avoid the precipitation of TCP phases, they are expected to appear in the microstructure after long exposure to high temperature.

The relevant literature does not provide much information on the effect of TCP phases on mechanical properties in single crystal materials. It is therefore of practical interest to collect and review all available data. This paper provides an overview of modern single crystal Ni-based superalloy systems, as well as the main principles of the design procedures and estimation of the microstructural stability for the highest generation single crystal Ni-based superalloys.

\section{ALLOYING ELEMENTS AND MICROSTRUCTURE}

$\mathrm{Ni}$-based superalloys typically contain up to 12 alloying elements. The main element is $\mathrm{Ni}$, which is used as the base material exhibiting an austenitic face-centered cubic (FCC) crystal lattice structure 
[7]. Low cost, slow rates of thermally activated creep process, high temperature strength, good ductility and toughness are other positive aspects, which can be assigned to Ni presence. Depending on the type and content of other alloying elements, the overall strength, the type and morphology of individual phases, microstructure stability, corrosion and oxidation resistance can be designed and refined. In current commercial single crystal Nibased superalloys the elements commonly added are: aluminium $(\mathrm{Al})$, boron $(\mathrm{B})$, carbon $(\mathrm{C})$, chromium $(\mathrm{Cr})$, cobalt $(\mathrm{Co})$, hafnium $(\mathrm{Hf})$, molybdenum (Mo), niobium $(\mathrm{Nb})$, rhenium $(\mathrm{Re})$, ruthenium $(\mathrm{Ru})$, tantalum $(\mathrm{Ta})$, titanium $(\mathrm{Ti})$, vanadium $(\mathrm{V})$, yttrium $(\mathrm{Y})$, zirconium $(\mathrm{Zr})$ and tungsten $(\mathrm{W})$. Not all of them are however necessary in a single alloy. Some of them have only one task, whereas others serve multiple functions. The segregation of individual elements into different phases in $\mathrm{Ni}$ based superalloys is presented in Figure 1.

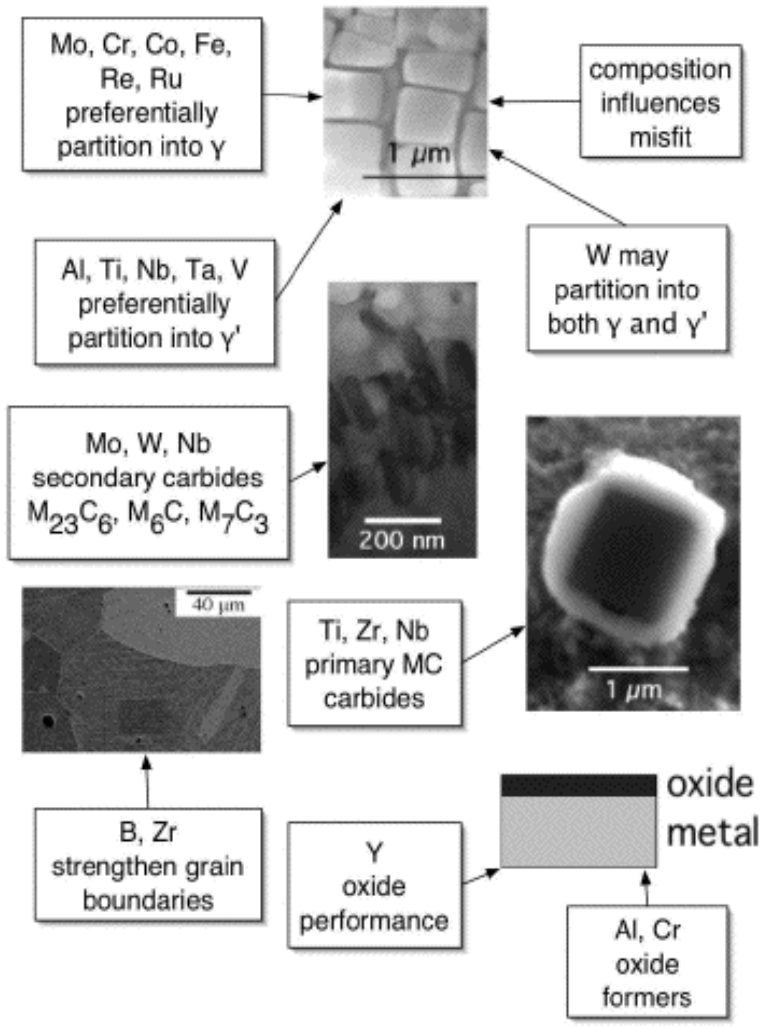

Figure 1 -The effect of alloying elements on nickel-based superalloys [8]

The alloying elements can be divided into different functional classes, in which a set of elements shows similar behavior. Elements such as $\mathrm{Co}, \mathrm{Cr}, \mathrm{Ru}, \mathrm{Re}, \mathrm{Mo}$ and $\mathrm{W}$ segregate to $\mathrm{y}$ phase and stabilize it due to similar size of their atomic radii to $\mathrm{Ni}$. On the other hand the $\mathrm{y}^{\prime}$ phase is stabilized by $\mathrm{Al}, \mathrm{Ta}$ and $\mathrm{Ti}$, which have larger atomic radii. Furthermore, in polycrystalline $\mathrm{Ni}$ based superalloys elements such as $\mathrm{B}, \mathrm{C}$ and $\mathrm{Zr}$ segregate to grain boundaries and reinforce them [9].

The aim of design procedures is to establish a given alloy composition, which will provide high tensile, creep and fatigue strength, long-term microstructural stability at high temperatures, and finally high resistance to oxidation and sulfidation. The specific roles of the alloying elements, their effects on mechanical and microstructural properties in Ni-based superalloys, and current design tendencies are described below.

Elements such as $\mathrm{Ti}, \mathrm{Ta}, \mathrm{Nb}, \mathrm{Re}, \mathrm{W}, \mathrm{Mo}$, and $\mathrm{Cr}$ are solid solution strengtheners. $\mathrm{Ta}, \mathrm{Ti}$, and $\mathrm{Nb}$ strengthen the $Y^{\prime}$ phase, while others called refractory elements strengthen the $y$ matrix. The latest trends in superalloys development show tendency to increase the overall content of refractory elements at the expense of Mo and $\mathrm{V}$, which lower oxidation resistance. However the overall content of refractory elements must be controlled to avoid formation of brittle phases, like topologically close packed (TCP) ones, which are detrimental to mechanical properties during high temperature exposure $[10,11,12]$. The significant issue for any Ni-based superalloy is good environmental stability. The addition of Mo, $\mathrm{W}$ or Re provides high strength, however they can significantly decrease microstructural stability. In order to prevent this, other elements like $\mathrm{Al}, \mathrm{Cr}$ and $\mathrm{Ru}$ [13] are added as well. Al and Cr help to form a protective $\mathrm{Al}_{2} \mathrm{O}_{3}$ or $\mathrm{Cr}_{2} \mathrm{O}_{3}$ oxide layer on the alloy surface. $\mathrm{Cr}$ is more effective in preventing hot corrosion and sulfidation, while $\mathrm{Al}$ is more stable at higher temperatures and gives better oxidation resistance. To obtain a good level of surface degradation resistance, high quantities of $\mathrm{Cr}$ or $\mathrm{Al}$ are therefore required.

A crucial element for consideration in Ni-based superalloys design is Re, which becomes increasingly popular in new generations of single crystalline superalloys. Under stress conditions at increased temperature, the alloy microstructure starts to evolve and raft. It was reported that rafting reduces the creep resistance under intermediatetemperature/intermediate-stress condition [14, 15, 16] however the formation of stable raft structure at temperatures higher than $1000^{\circ} \mathrm{C}$ can successfully extend the creep rupture life [17]. Therefore, modern superalloys have been developed with the addition of Re to improve creep properties $[18,19]$. $\mathrm{Re}$ in combination with Mo changes lattice misfit towards larger negative values, which creates dense interfacial networks of misfit dislocation [20]. As more dislocations settle at the interface, the mesh spacing gets smaller and will further prevent dislocations from entering and shearing the $Y$ ' precipitates [21]. A clear relationship between 
mean dislocation network spacing at the $\mathrm{y} / \mathrm{y}^{\prime}$ interfaces and the minimum creep rate was shown in the work of Koizumi et al. [22]. As the spacing becomes finer, the creep rate drastically decreases. The opposite effect to Mo and Re was observed for $\mathrm{Ta}$ and $\mathrm{Nb}$, which tend to bring lattice misfit between $y$ and $y^{\prime}$ phases closer to zero. In consequence, the dislocation network becomes coarser and creep deformation by dislocation cutting is easier to occur [22]. Another element, which improves creep properties, is Co. It reduces the stacking fault energy and makes dislocation cross slip around y' particles more difficult [23, 24]. Furthermore, Co and $\mathrm{Ru}$ were found to suppress

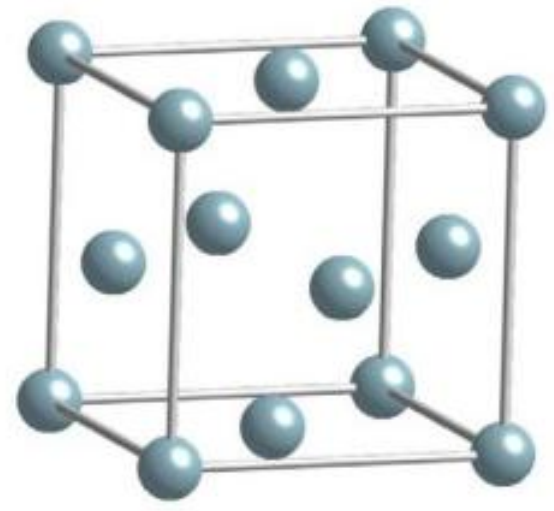

(a)
TCP formation at high temperature exposure [25, 26].

The typical Ni-based superalloy microstructure consists of two main phases:

1. The $y$ phase, i.e. the matrix phase with a disordered face centered cubic (FCC) crystal lattice structure, Figure 2 (a), which contains mainly solidsolution elements such as $\mathrm{Co}, \mathrm{Cr}, \mathrm{Re}, \mathrm{W}$.

2. The $y^{\prime}$ phase, i.e. the precipitate phase, which enhances the material overall strength at elevated temperatures. It is composed mostly of $\mathrm{Ni}$, Al which constitute an $\mathrm{L}_{2}$ ordered structure like $\mathrm{Ni}_{3} \mathrm{Al}$, having $\mathrm{Ni}$ atoms at unit cell face centers and $\mathrm{Al}$ atoms at the corners Figure 2 (a), (b).

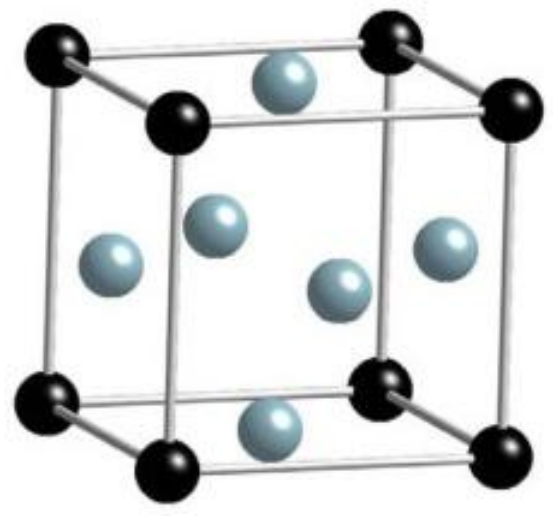

(b)

Figure 2 - Crystal structure of (a) y phase with all unit cell corners occupied by Ni atoms (grey) and (b) $\mathrm{Ni}_{3} \mathrm{Al}$ Y' phase with Al atoms (black) at corners and Ni atoms (grey) at the face centers [27]

The $\mathrm{y}^{\prime}$ phase is coherent with the $\mathrm{Y}$ matrix and forms finely dispersed particles. From the thermodynamic point of view the $y / \gamma^{\prime}$ microstructure is usually in metastable state. Depending on the chemical composition and the applied heat treatment, $Y^{\prime}$ particles can change their arrangement, shape (spherical, cuboidal) and size $[28,29,30]$. The typical commercial Ni-based superalloys contain around 65 vol. \% fraction of $y$ ' phase, which is stated as the optimal value to ensure the best creep rupture properties at high temperatures [33]. However, the $Y$ ' fraction should not be treated as the only factor imparting high mechanical properties. The other factor is the chemical composition that affects the chemistry of precipitates and consequently the lattice mismatch. Both the chemistry and the mismatch indeed can extensively influence the mechanical properties.

\section{CLASSIFICATION}

The presented classification focuses on single crystal Ni-based superalloys. This group of alloys is patented by the US Patent 5366695 [32] and can be classified into different generations. Until today there are six generations of Ni-based SC crystal superalloys. A simple method to assign most of them to an appropriate generation was presented in Figure 3. This figure presents the differences in $\mathrm{Re}$ and Ru content for generations from 1 to 5 .

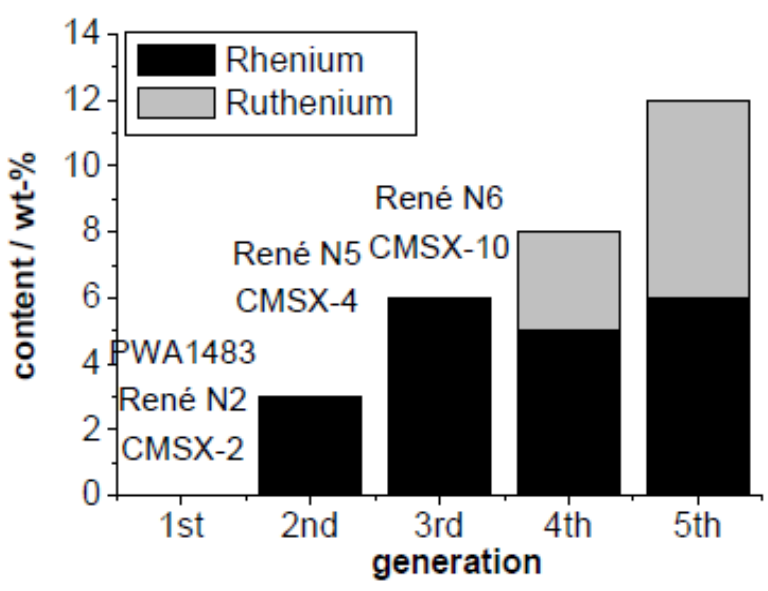

Figure 3 - Ru and Re content for different generation of single crystal nickel-based superalloys [33]

Except generation number 6 , which is not included in this plot, they can be easily distinguished by the content of $\mathrm{Re}$ and $\mathrm{Ru}$. In the first generation alloy these elements were not added. In order to 
improve the strength and fatigue life, $R e$ is added up to approximately $3 \mathrm{wt}$. \% and 6 wt. \% in the second and third generation respectively. The main difference in fourth generation is the Ru content of about 3 wt. \% to achieve better microstructural stability. Compared to previous generations, the latter one exhibits improved creep behavior at high temperatures, which is attributed to the finer interfacial dislocation network [34]. The fifth generation has the same level of Re content as the fourth one, however the Ru content is increased to 5 wt. \%.

Table 1 - Chemical composition of single crystal nickel-based superalloys classified from the first to sixth generation [1, 35]

\begin{tabular}{|c|c|c|c|c|c|c|c|c|c|c|c|c|}
\hline & $\mathrm{Cr}$ & Co & Mo & $\mathrm{W}$ & $\mathrm{Al}$ & $\mathrm{Ti}$ & $\mathrm{Ta}$ & $\mathrm{V}$ & $\mathrm{Nb}$ & $\mathrm{Hf}$ & $\operatorname{Re}$ & $\mathrm{Ru}$ \\
\hline \multicolumn{13}{|c|}{$1^{\text {st }}$ generation } \\
\hline AM1 & 8 & 6 & 2 & 6 & 5.2 & 1.2 & 9 & - & - & - & - & - \\
\hline AM3 & 8 & 6 & 2 & 5 & 6 & 2 & 4 & - & - & - & - & - \\
\hline AF56 & 12 & 8 & 2 & 4 & 3.4 & 4.2 & 5 & - & - & - & - & - \\
\hline CMSX-2 & 8 & 5 & 0.6 & 8 & 5.6 & 1 & 6 & - & - & - & - & - \\
\hline CMSX-3 & 8 & 5 & 0.6 & 8 & 5.6 & 1 & 6 & - & - & 0.1 & - & - \\
\hline CMSX-6 & 10 & 5 & 3 & - & 4.8 & 4.7 & 2 & - & - & 0.1 & - & - \\
\hline PWA1480 & 10 & 5 & - & 4 & 5 & 1.5 & 12 & - & - & - & - & - \\
\hline Rene' N4 & 9 & 8 & 2 & 6 & 3.7 & 4.2 & 4 & - & 0.5 & - & - & - \\
\hline RR2000 & 10 & 15 & 3 & - & 5.5 & 4 & & 1 & - & - & - & - \\
\hline SRR99 & 8 & 5 & - & 10 & 5.5 & 2.2 & 3 & - & - & - & - & - \\
\hline \multicolumn{13}{|c|}{$2^{\text {nd }}$ generation } \\
\hline CMSX-4 & 7 & 9 & 0.6 & 6 & 5.6 & 1 & 7 & - & - & 0.1 & 3 & - \\
\hline PWA1484 & 5 & 10 & 2 & 6 & 5.6 & - & 9 & - & - & 0.1 & 3 & - \\
\hline Rene' N5 & 7 & 8 & 2 & 5 & 6.2 & - & 7 & - & - & 0.2 & 3 & - \\
\hline SC180 & 5 & 10 & 2 & 5 & 5.2 & 1 & 9 & - & - & 0.1 & 3 & - \\
\hline \multicolumn{13}{|c|}{$3^{\text {rd }}$ generation } \\
\hline CMSX-10 & 2 & 3 & 0.4 & 5 & 5.7 & 0.2 & 8 & - & - & 0.03 & 6 & - \\
\hline Rene' N6 & 4.2 & 12.5 & 1.4 & 6 & 5.75 & - & 7.2 & - & 0.1 & 0.15 & 5.4 & - \\
\hline TMS-75 & 3 & 12 & 2 & 6 & 6 & - & 6 & - & - & 0.1 & 5 & - \\
\hline TMS-113 & 2.9 & 11.9 & 2 & 6 & 6.6 & - & 6 & - & - & 0.1 & 6 & - \\
\hline TMS-121 & 3 & 6 & 3 & 6 & 6 & - & 6 & - & - & 0.1 & 5 & - \\
\hline \multicolumn{13}{|c|}{$4^{\text {th }}$ generation } \\
\hline MC-NG & 4 & - & 1 & 5 & 6 & 0.5 & 5 & - & - & 0.1 & 4 & 4 \\
\hline PWA1497 & 2 & 16.5 & 2 & 6 & 5.6 & - & 8.3 & - & - & 0.15 & 6 & 3 \\
\hline TMS-138 & 3.2 & 5.8 & 2.9 & 5.9 & 5.8 & - & 5.6 & - & - & 0.1 & 5 & 2 \\
\hline TMS-138+ & 3.2 & 5.8 & 2.9 & 5.6 & 5.7 & - & 5.6 & - & - & 0.1 & 5.8 & 3.6 \\
\hline \multicolumn{13}{|c|}{$5^{\text {th }}$ generation } \\
\hline TMS-162 & 3 & 5.8 & 3.9 & 5.8 & 5.8 & - & 5.6 & - & - & 0.1 & 4.9 & 6 \\
\hline TMS-173 & 3 & 5.6 & 2.8 & 5.6 & 5.6 & - & 5.6 & - & - & 0.1 & 6.9 & 5 \\
\hline TMS-196 & 4.6 & 5.6 & 2.4 & 5 & 5.6 & - & 5.6 & - & - & 0.1 & 6.4 & 5 \\
\hline \multicolumn{13}{|c|}{$6^{\text {th }}$ generation } \\
\hline TMS-238 & 4.6 & 6.5 & 1.1 & 4 & 5.9 & - & 7.6 & - & - & 0.1 & 6.4 & 5 \\
\hline
\end{tabular}

Table 1 presents examples of chemical compositions of superalloys belonging to different generations. The newest single crystal superalloys from the $4^{\text {th }}, 5^{\text {th }}$, and $6^{\text {th }}$ generation were mainly developed by the National Institute of Material Science (NIMS) in Japan. According to the NIMS Alloy Design software (NIMS-ADP) [36] material parameters including phase composition and volume fractions, alloy density, phase stability, lattice misfit, creep strengths were taken into account [22, 35]. To improve the oxidation resistance, $\mathrm{Cr}$ content was increased in the highest generation alloys to $4,6 \mathrm{wt}$. \%. The fine adjustment of Mo, W, Re and Ru concentration allow to keep the $y^{\prime}$ volume fraction constant, and maintain the microstructural stability and lattice misfit on acceptable levels. The $5^{\text {th }}$ generation superalloys exhibit not only superior high temperature creep and thermo-mechanical fatigue resistance by incorporating higher content of $\mathrm{Re}$, but also good 
microstructural stability due to higher $\mathrm{Ru}$ content than in the $4^{\text {th }}$ one [37]. However, it has been proven by Walston and Kawagishi $[25,38]$ that $4^{\text {th }}$ and $5^{\text {th }}$ generations are likely to have lower oxidation resistance than previous ones due to higher content of refractory elements. TMS-238 alloy ( $6^{\text {th }}$ generation) was thus designed to have similar mechanical properties to $5^{\text {th }}$ generation superalloys, but improved oxidation and hotcorrosion resistance. The composition of TMS-196 $\left(5^{\text {th }}\right.$ generation) was used as a reference. The Mo and $\mathrm{W}$ contents were reduced, while $\mathrm{Co}$ and $\mathrm{Ta}$ contents were increased. The comparison of mechanical and oxidation properties for different generations of superalloys was presented in Kawagishi's work [39]. His results are shown in Figure 4 and Figure 5, where the Larson-Miller diagram of creep properties and the oxidation tests are displayed, respectively. The creep rupture life of TMS-238 is comparable to other alloys, while the oxidation test shows significant improvement in surface stability over the $4^{\text {th }}$ and $5^{\text {th }}$ generation alloys.

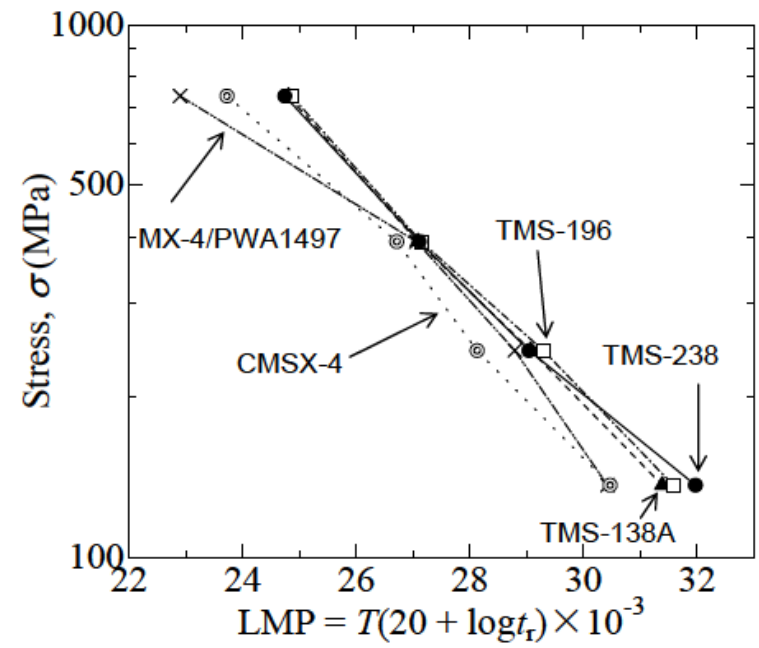

Figure 4 - Larson-Miller diagram of creep properties for different generations of $\mathrm{Ni}$-based superalloys [39]

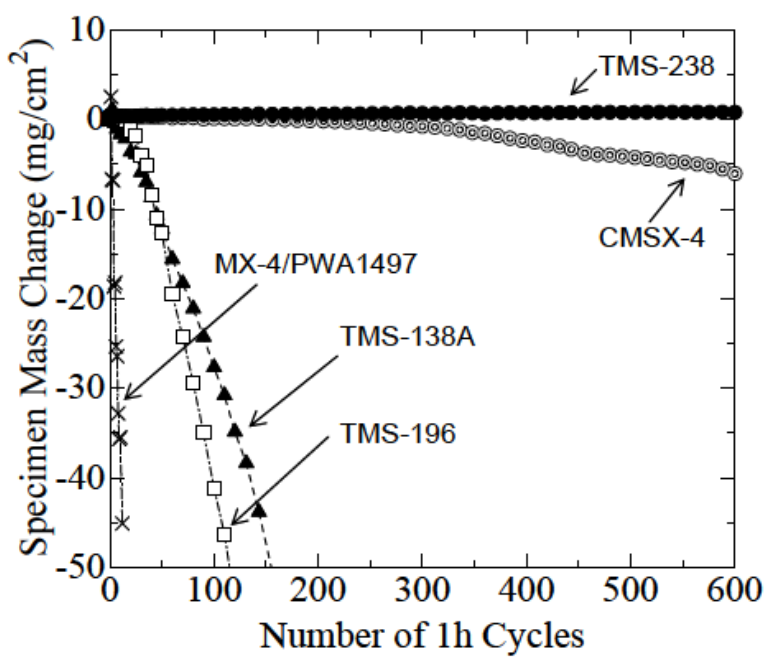

Figure 5 - Cyclic oxidation tests performed at $1100^{\circ} \mathrm{C}$ for different generations of Ni-based superalloys [39]

\section{MICROSTRUCTURE STABILITY AT HIGH TEMPERATURE}

High content of refractory elements in modern single crystal superalloys may cause extensive formation of TCP phases during long-term exposure to high temperatures. The region in which TCPs precipitates, strongly depends on the material microstructure. In case of single crystal alloys they usually form in dendrite core areas, Figure 6, while for alloys having a granular structure, the TCP phases can precipitate at grain boundaries in form of cellular colonies, Figure 7. TCP phases are composed mainly of $\mathrm{Ni}, \mathrm{Cr}, \mathrm{Mo}$, Co, $\mathrm{W}$ and $\mathrm{Re}$, however the content of individual elements can vary significantly and depends on TCP type and alloy composition. Table 2 presents four main types of TCP phases, which can be distinguished in the available literature. They form in an extensive plate-like morphology. The closepacked layers have a high degree of coherency with the four $\{111\}$ planes of the $Y$ and $Y$ ' phases, which results in characteristic needle-like structure, when sectioned in the $\{100\}$ plane.

Table 2 - Crystallography of the TCP phases [12, 42]

\begin{tabular}{|c|c|c|c|c|l|c|}
\hline $\begin{array}{c}\text { Type of } \\
\text { TCP phase }\end{array}$ & System & $\begin{array}{c}\text { Space } \\
\text { Group }\end{array}$ & $\begin{array}{c}\text { Space } \\
\text { group No. }\end{array}$ & $\begin{array}{c}\text { Atoms per } \\
\text { Unit Cell }\end{array}$ & Lattice Parameter & $\alpha$ \\
\hline$\sigma$ & Tetragonal & $\mathrm{P}_{2} / \mathrm{mnm}$ & 136 & 30 & $\begin{array}{l}\mathrm{a}=\mathrm{b}=0.878 \mathrm{~nm}, \\
\mathrm{C}=0.454 \mathrm{~nm}\end{array}$ & $90^{\circ}$ \\
\hline $\mathrm{P}$ & Orthorhombic & Pnma & 62 & 56 & $\begin{array}{l}\mathrm{a}=1.698 \mathrm{~nm}, \mathrm{~b}=0.475 \mathrm{~nm}, \\
\mathrm{C}=0.907 \mathrm{~nm}\end{array}$ & $90^{\circ}$ \\
\hline$\mu$ & $\begin{array}{c}\text { Rhombohedral } \\
\text { Hexagonal }\end{array}$ & R-3m & 166 & $\begin{array}{c}13 \\
\text { (hex. 39) }\end{array}$ & $\begin{array}{l}\mathrm{a}=\mathrm{b}=\mathrm{C}=0.904 \mathrm{~nm} \\
\mathrm{a}=\mathrm{b}=0.476 \mathrm{~nm}, \\
\mathrm{C}=2.583 \mathrm{~nm}\end{array}$ & $\begin{array}{c}30.5^{\circ} \\
120^{\circ}\end{array}$ \\
\hline $\mathrm{R}$ & Rhombohedral & $\mathrm{R}-3$ & 148 & 53 & $\begin{array}{l}\mathrm{a}=\mathrm{b}=1.093 \mathrm{~nm}, \\
\mathrm{c}=1.934 \mathrm{~nm}\end{array}$ & $120^{\circ}$ \\
\hline
\end{tabular}




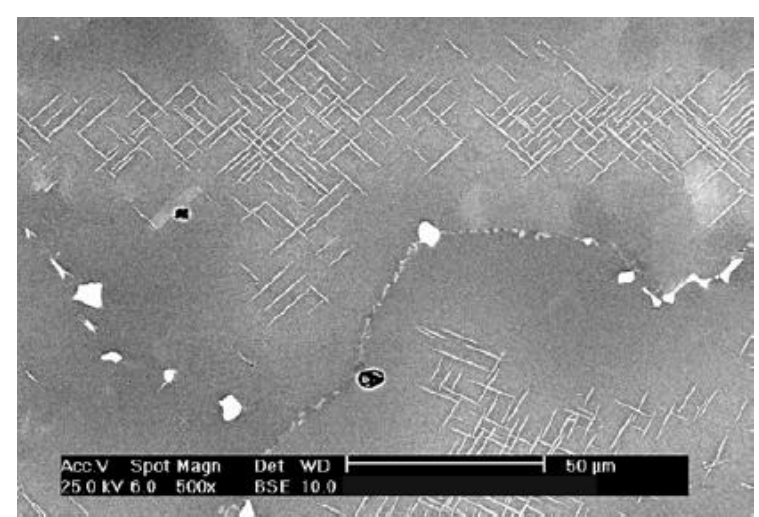

Figure 6 - SEM image of TCP phase formation in dendritic region of nickel-based superalloys.[40]
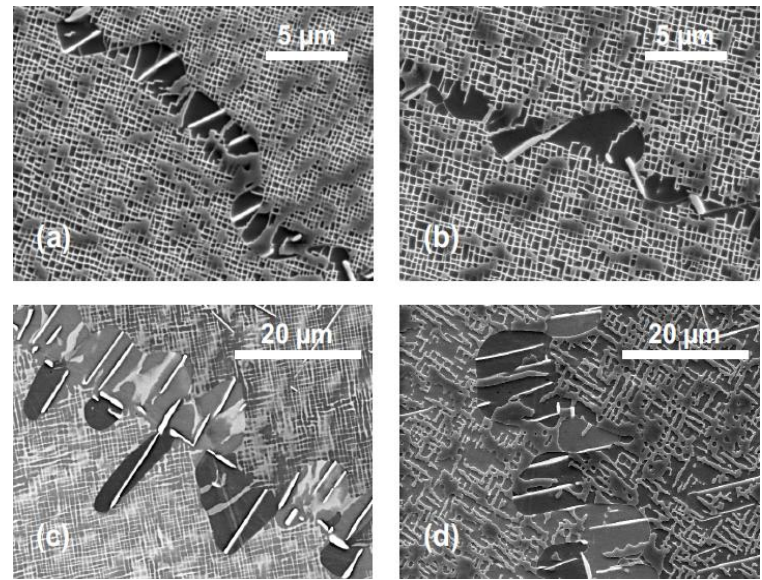

Figure 7 - SEM images (backscattered electron mode) of TCP precipitates within cellular colonies at high angle subgrain boundaries in Ni-based superalloy: as heat treated (a); aged for 200 hours at $950^{\circ} \mathrm{C} \mathrm{(b);} 1050^{\circ} \mathrm{C} \mathrm{(c)} \mathrm{and} 1100^{\circ} \mathrm{C}(\mathrm{d})$ [41]

Research on high generation single crystal $\mathrm{Ni}$ based superalloys showed that thermal conditions expected during the service may be dangerous with respect to TCP formation, particularly in the temperature range between $900^{\circ} \mathrm{C}$ and $1100^{\circ} \mathrm{C}$. However, the exact temperature range at which the TCPs start to precipitate depends not only on temperature and time, but also on the chemical composition and segregation level. To investigate these aspects the chemical composition of various alloys was analyzed with focus on the tendency of TCP formation. Based on compositions and TimeTemperature-Transformation (TTT) diagrams for $3^{\text {rd }}$ and $4^{\text {th }}$ generation superalloys, Figure $8 \mathrm{a}$ ) and b) rough estimation of microstructural stability of $5^{\text {th }}$ and $6^{\text {th }}$ generation superalloys was performed. It was experimentally proven that the $4^{\text {th }}$ generation has superior microstructural stability than the $3^{\text {rd }}$ generation. These diagrams indicate the temperature window between $1000^{\circ} \mathrm{C}$ and $1200^{\circ} \mathrm{C}$ as the most critical temperature range, where TCP phase precipitation is the most extensive. Based on already collected information about the effect of alloying elements on microstructural stability, it can be concluded that the $5^{\text {th }}$ and $6^{\text {th }}$ generation alloys have compositions for which TCP phases are difficult to form. Besides the fact that $\mathrm{Re}$ content was slightly increased (from 5.8 to $6.4 \%$ ), all other changes, such as higher $\mathrm{Ru}$ and $\mathrm{Co}$ as well as lower W, Mo contents bring positive effect on TCP formation.

Considering microstructural stability of a material, not only the chemical composition must be addressed, but also the heat treatment. In terms of TCP formation the important aspect is material homogenization. Due to different diffusion coefficients of each element, too short homogenization heat treatments result in differences in chemical composition for dendritic and interdendritic areas. In such a type of structure, TCP phase precipitation is easy to occur in dendrite cores due to higher local content of refractory elements. For this reason long homogenization heat treatment at high temperature should be performed.
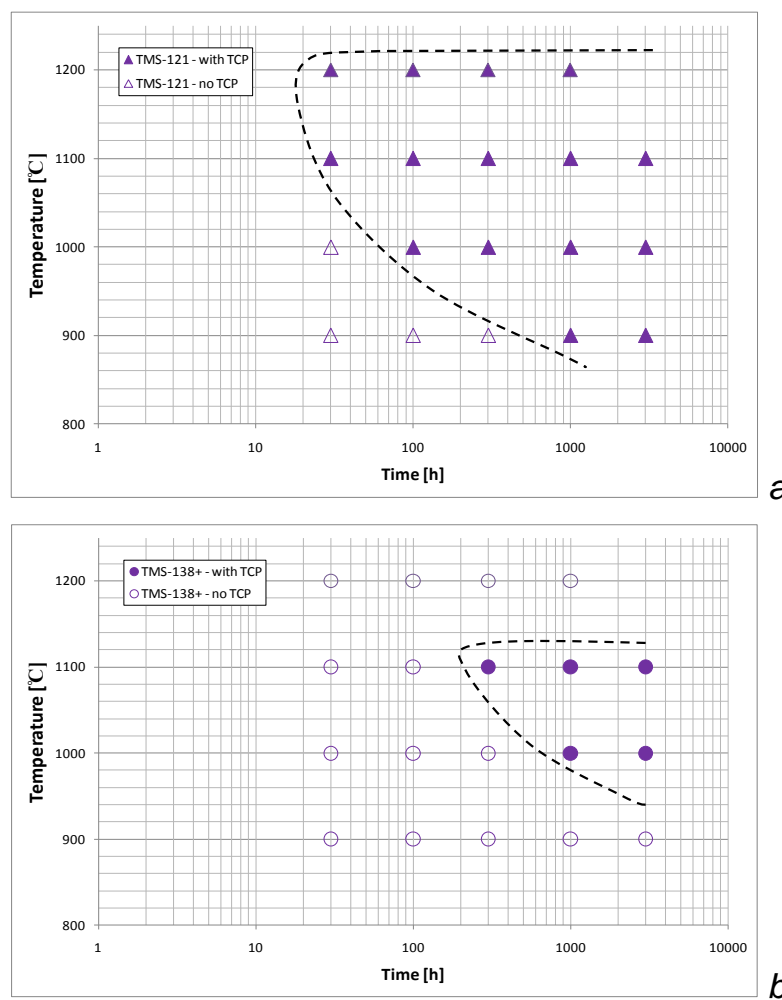

Figure 8 - TTT diagrams for TMS-121 (a) as a $3^{\text {rd }}$ generation and TMS-138+ (b) as a $4^{\text {th }}$ generation Ni-based superalloys [43]

TCP phases are generally brittle and detrimental to mechanical properties. Their precipitation during the service depletes the matrix from refractory elements and reduces the solid solution effect. Moreover the TCP phases are often associated with the formation of voids at high temperatures, which may act as an initiation sites for fracture [44]. However, there is conflicting data whether they are responsible for failure and fracture of single crystal alloys $[45,46]$. Most of the 
papers describe the detrimental effect of TCP phases on creep properties. However, to elucidate it, the effect of $y^{\prime}$ coarsening on alloy strength must be separated from the effect due to the formation of TCP.

Such investigation was performed by Volek [40], who used different solidification conditions to obtain two different sets of samples: one with coarse and a second with fine dendrite structure. It was confirmed in this work that TCP formation is occurs more likely in the material with coarser dendrite structure. This methodology allowed to compare the influence of TCP phases on mechanical properties for the same alloy composition, i.e. without aging impact on the $y^{\prime}$ phase. Unfortunately, the analyzed samples demonstrated significant changes in casting porosity. Finer dendrite structure contained a high number of small pores, while coarser dendrite structure exhibited an opposite effect with a low number of large pores. Therefore, the results obtained by this author in fact are due to combined effect of various degree of TCP precipitation and pore size distribution.

\section{CONCLUSIONS}

Single crystal Ni-based superalloys are developed especially for the most critical elements applied in high temperatures and load conditions. They exhibit excellent creep, oxidation and corrosion resistance and for these reasons are mostly used in aerospace and nuclear industry.

The aim of the design procedures is to establish a given alloy composition, which will provide high tensile, creep and fatigue strength, long-term microstructural stability at high temperatures, and finally high resistance to oxidation and sulfidation. The latest trends show tendency to increase the overall content of refractory elements. However this may cause extensive formation of detrimental to mechanical properties TCP phases in superalloys microstructure after long term exposure. An interesting issue for future experiments would be the determination only of the effect of TCP phases on mechanical properties with focus on creep and fatigue properties. Nevertheless correct understanding of the precipitation process and finding the correlation with alloying elements allows diminishing this effect in newly developed materials.

\section{REFERENCES}

[1] M.Gebura (2008) Chemical composition and classification of single crystal Nickel-based superalloys, Materialovy inzynier, 2007-2009.

[2] N.S.Stoloff, D.J.Duquette (1993) Critical issues in the development of high temperature structural materials, TMS, 189-202.

[3] A.F.Giamei, D.L.Anton (1985) Rhenium Additions to a Nickel-base Superalloy: Effects on Microstructure, Metal. Tram. A, 16, 1997-2005.
[4] K.Harris, G.L.Erickson, S.L.Sikkenga, W.Brentnall, J.M.Aurrecoechea, K.G.Kubarych (1992) Development of the rhenium-containing superalloys CMSX-4 \& CM186LC for single crystal blade and directionally solidified vane applications in advanced turbine engines, Superalloys, 297-306.

[5] A.K.Sinha (1972) Topologically Close-Packed Structures of Transition Metal Alloys, Progress in Materials Science, 15, 81-185.

[6] R.L.Dresfield, R.L.Ashbrook (1970) Further observations on the formation of sigma pchase in a Nikel-base superalloy (IN-100), NASA Technical Note, NASA TN D-6015.

[7] D.R.Askeland, P.P.Fulay, W.J.Wright (2010) The Science and Engineering of Materials, Cengage Learning.

[8] H.K.D.H.Bhadeshia, University of Cambridge (2003) Nickel-based Superalloys (http://www.msm.cam. ac .uk/phase-trans/2003/Superalloys/superalloys.html).

[9] R.Sinclar, J.A.Leake, B.Ralph (1974) Spinodal decomposition of a nickel- titanium Alloy, Phys. Status Solidi., 26, 285-298.

[10] [E.M.Mueller (2003) The Characterization of Freckle Casting Defects in Directionally Solidified Nickel-Base Superalloy Turbine Blades, PhD thesis, University of Florida, USA.

[11] T.Hino, Y.Yoshioka, K.Nagata, H.Kashiwaya, T.Kobayashi, Y.Koizumi, H.Harada, T.Yamagata (1998) Design of a high Re containing single crystal superalloys for industrial gas turbines, Proc. 6th Liege Conference on Materials for Advanced Power Engineering, 1129-1137.

[12] C.M.F.Rae, M.S.A.Karunaratne, C.J.Small, R.W.Broomfield, C.N.Jones, R.Reed (2000) Topologically Close Packed Phases in an Experimental Rhenium-Containing Single Crystal Superalloy, Superalloys, 767-776.

[13] J.C.M.Li (1996) Microstructure and Properties of Materials (volume 1), World Scientific Publishing Co. Pte. Ltd.

[14] C.Carry J.L.Strudel (1978) Apparent and Effective Creep Parameters in Single Crystals of a Nickel-based Superalloy-II. Secondary Creep, Acta Metal., 26, 859870.

[15] M.V.Nathal L.J.Ebert (1985) Elevated Temperature Creep-Rupture Behavior of the Single Crystal NickelBase Superalloy NASAIR 100, Metal. Trans. A, 16 , 427-439.

[16] W.Schneider, J.Hammer H. Mughrabi (1992) Creep Deformation and Rupture Behaviour of the Monocrystalline Superalloy CMSX-4 - A Comparison with the Alloy SRR 99, Superalloys, 589-598.

[17] F.R.N.Nabarro (1995) Rafting in Superalloys, Met. Mat. Trans. A, 27, 513-529.

[18] G. L.Erickson (1996) The development and application of CMSX-10, Superalloys, p.35-44.

[19] Y.Murata, R.Hashizume, A Yoshinari (2000) Alloying effects on surface stability and creep strength of Nickel-based single crystal superalloys containing $12 \mathrm{mass} \% \mathrm{Cr}$, Superalloys, 285-294.

[20] J.X.Zhang, T.Murakumo, Y.Koizumi, T.Kobayashi, H.Harada, S.Masaki (2002) Interfacial Dislocation Networks Strengthening a Fourth-Generation SingleCrystal TMS-138 Superalloy, Metallurgical and Materials Transactions A, 33, 3741-3746. 
[21] B.C.Wilson, D.E.Fuchs (2008) The effect of composition, misfit, and heat treatment on the primary creep behavior of single crystal nickel-based superalloys PWA 1480 and PWA 1484, Superalloys, 149-158.

[22] Y.Koizumi, T.Kobayashi, T.Yokokawa, J.Zhang, M. Osawa, H.Harada, Y.Aoki, M.Arai (2004) Development of Next-Generation Nickel-Base Single Crystal Superalloys, TMS, 35-43.

[23] C.T.Sims, N.S.Stoloff, W.C.Hagel (1987) Superalloys II, John Wiley \& Sons, New York.

[24] G.E.Dieter (1961) Mechanical Metallurgy, McGraw-Hill, New York.

[25] S.Walston, A.Cetel, R.MacKey, K. O'Hara, D.Duhl, R.Dreshfield (2004) Joint Development of Forth Generation Single Crystal Superalloy, TMS, 15-24.

[26] S.Li, X.Xie, L.Jiang, Y.Han (2011) Effect of Ru on microstructure stability and mechanical properties on $\mathrm{Ni}_{3} \mathrm{Al}$ single crystal alloy, Materials International, 21, 286-292.

[27] M.Chaudhari (2012) First principles calculations of the site substitution behavior in gamma prime pchase in Nikel based superalloys, PhD Thesis, University of north Texas, USA.

[28] T.P.Gabb, D.G.Backman, D.Y.Wei, D.P.Mourer, D.Furrer, A.Garg, D.L.Ellis (2000) y' formation in a nickel-base disk superalloy, Superalloys, 405-414.

[29] P.Wangyao, N.Chuankrerkkul, S.Polsilapa, P. Sopon, W.Homkrajai (2009) Gamma Prime Phase Stability after Long-Term Thermal Exposure in Cast Nickelbased Superalloy, IN738, Chiang Mai J. Sci., 36(3), 312-319.

[30] A.Lavakumar, P.K.Singh, S.Srivastava, S.Kori, L.A.Kumar (2013) Gamma Prime Coarsening Behavior of Nickel Super alloy Super cast 247A after Prolonged Thermal Exposures, IOSR Journal of Mechanical and Civil Engineering, 37-42.

[31] Y.Ro, Y.Koizumi H.Harada (1997) High temperature tensile properties of a series of nickel-base superalloys on $y / y^{\prime}$ tie line, Mater. Sci. Eng. A223, 59-63.

[32] G.L.Ericson (1994) CMSX-10 Alloy, USA Patent, No. 5366695.

[33] R.Rettig, R.F.Singer (2009) Modelling of long-term phase stability in Ni-based superalloys based on thermodynamic and kinetic CALPHAD calculations, ThermoCalc User Meeting - Aachen.

[34] Z.Hao, Y.Ro, H.Harada, Y.Aoki, M.Arai (2004) Deformation microstructures after low-cycle fatigue in a fourth-generation Ni-base SC superalloy TMS-138, Mater. Sci. Eng. A 381, 20-27.
[35] A.Sato, H.Harada, A.C.Yeh, K.Kawagishi, T. Kobayashi, Y.Koizumi, T.Yokokawa, J.X.Zhang (2008) A 5th Generation SC Superalloy with Balanced High Temperature Properties and Processability, Superalloys, 131 138.

[36] H.Harada, K.Ohno, T.Yamazaki, T.Yokokawa M. Yamazaki (1988) Phase Calculation and Its Use in Alloy Design Program for Nickel-base Superalloys, Superalloys, 733-742.

[37] National Institute for Material Science (NIMS) (2010) Research and development of superalloys for aeroengine applications (http://sakimori.mins.go. jp/topics/hightemp_e.pdf).

[38] K.Kawagishi, A.Sato, T.Kobayashi, H.Harada (2005) Effect of Alloying Elements on the Oxidation Resistance of 4th Generation Ni-base Single-crystal Superalloys, J. Japan Inst. Metals, 69, 249-252.

[39] K.Kawagishi, A.C.Yeh, T.Yokokawa, T.Kobayashi, Y.Koizumi, H.Harada (2012) Development of an Oxidation-resistant High-strength Sixth-generation Single-crystal Superalloy TMS-238, Superalloys, p.189-195.

[40] A.Volek, R.F.Singer (2004) Influence of Solidification Conditions on TCP Phase Formation, Casting Porosity and High Temperature Mechanical Properties in a ReContaining Nickel-Base Superalloy with Columnar Grain Structure, Superalloys, 713-718.

[41] O.Lavigne, C.Ramusat, S.Darwin, P.Caron, D. Boivin, J.L.Pouchou (2004) Relationships between microstructural instabilities and mechanical behaviour in new generation nickel-based single crystal superalloys, Superalloys, p.667-675.

[42] R.Darolia, D.F.Lahrman, R.D.Field (1988) Formation of Topologically Closed Packed Phases in Nickel-based Single Crystal Superalloys, Superalloys, 255-264.

[43] A.Sato, H.Harada, T.Yokokawa, T.Murakumo, Y.Koizumi, T.Kobayashi, H.Imai (2006) The effect of ruthenium on the pchase stability of fourth generation Ni-base single crystal superalloys, Scripta Materialia, 54, 1679-1684.

[44] M.Pessah, P.Caron, T.Khan (1992) Effect of $\mu$ phase on the mechanical properties of a Nikel-base single crystal superalloys, Superalloys, 567-576.

[45] C.Proctor (1993) Formation and effects of intermetallics in the Re- containing superalloy CMSX-4, PhD Thesis, University of Cambridge, G.B.

[46] T.Yokokawa, M.Osawa, H.Murakami, T.Kobayashi, Y.Koizumi, T.Yamagata, H.Harada (1998) Design of high $\mathrm{Re}$ containing single crystal superalloys for industrial gas turbines, Materials for Advanced Power Engineering, p.1121-1128.

\section{IZVOD}

\section{KLASIFIKACIJA I MIKROSKOPSKA STABILNOST VISOKE GENERACIJE MONO KRISTALA SUPERLEGURE NA BAZI NIKLA}

$U$ ovom radu dat je kratak pregled različitih tipova mono-kristalnih super-legura na bazi Ni koje su dizajnirane u novije vreme. Naglašeni su principi dizajniranja ovih legura sa ciljem da se postignu zahtevane mehaničke osobine i mikrostukturna stabilnost za vreme dugotrajnog izlaganja visokim temperaturama. Glavna pažnja je posvećena legurama sa visokim sadržajem vatrostalnih materijala. Posebno je naglašeno formiranje krtih faza, kao što su topološki blisko upakovane faze, koje negativno utiču na mehaničke osobine mono-kristalnih super-legura na bazi Ni.

Ključne reči: mono-kristalne super-legure na bazi Ni, topološki blisko upakovane faze, $\gamma, \gamma$ '

Naučni rad

Rad primljen: 09. 02. 2016.

Rad prihvaćen: 24. 03. 2016.

Rad je dostupan na sajtu: www.idk.org.rs/casopis 